\title{
Place-Based Directionality of Innovation: Tasmanian Salmon Farming and Responsible Innovation
}

\author{
Arnt Fløysand *, Emil Tomson Lindfors (D), Stig-Erik Jakobsen and Lars Coenen \\ The Mohn Centre for Innovation and Regional Development, Western Norway University of Applied Sciences, \\ NO 5063 Bergen, Norway; emil.tomson.lindfors@hvl.no (E.T.L.); sjak@hvl.no (S.-E.J.); Lars.Coenen@hvl.no (L.C.) \\ * Correspondence: arnt.floysand@hvl.no
}

Citation: Fløysand, A.; Lindfors, E.T.; Jakobsen, S.; Coenen, L. Place-Based Directionality of Innovation: Tasmanian Salmon Farming and Responsible Innovation. Sustainability 2021, 13, 62. https://dx.doi.org/10.33 90/su13010062

\section{Received: 28 October 2020}

Accepted: 20 December 2020

Published: 23 December 2020

Publisher's Note: MDPI stays neutral with regard to jurisdictional claims in published maps and institutional affiliations.

Copyright: () 2020 by the authors. Licensee MDPI, Basel, Switzerland. This article is an open access article distributed under the terms and conditions of the Creative Commons Attribution (CC BY) license (https: / / creativecommons.org/ licenses/by/4.0/).

\begin{abstract}
The aim of this paper has been to explore, in depth, the place-based conditions enabling and constraining the directionality of responsible innovation in the Tasmanian salmon farming industry, and to discuss how this case can inform the broader literature on directionality of innovations. Theoretically, we argue that the combination of literature on responsible research and innovation (RRI), regional innovation system (RIS) and discourse theory is a useful starting point for addressing innovation as a territorial complex consisting of a material dimension in terms of technologies and resources, an organizational dimension in terms of innovation systems and regulations, and a discursive dimension in terms of narratives in play. When applying the complex to analyze how place-based conditions have enabled and constrained the directionality of responsible innovation in the Tasmanian salmon industry, the case discerns that the directionality of responsible innovation arises from a rather mature and well-organized regional innovation system, which allows multiple stakeholders to articulate their narratives. Under such circumstances, responsible innovation becomes a multidimensional, interactive, and co-created phenomenon consisting of several dilemmas. Still, although the contextualization of responsible innovation is highlighted, our case study acknowledges that certain "universal" characteristics shine through. By this we mean that context sensitivity must not supersede the fact that place-based responsible innovation is always subject to some generic dynamism: under all circumstances there will be a territorial innovation complex at play.
\end{abstract}

Keywords: responsible innovation process; territorial innovation complex; Tasmanian salmon industry; place-based directionality

\section{Introduction}

Responsible research and innovation (RRI) has gained considerable prominence within policy spheres over the last decade, particularly in the EU, and has quickly grown as a scholarly topic of analysis and research in its own right [1,2]. The RRI literature has contributed insight into how to ensure the stewardship of technological research and innovation, how to anticipate the social impact of research, and how to make research and innovation more inclusive and sustainable [3]. Building on a technology assessment tradition, the RRI literature offers "forward-looking approaches, methods, and frames of reference for reflecting on the societal impact of research and innovation" [4]. In this sense, RRI taps directly into issues of directionality and normativity, bringing up questions about the types of value that are fostered by technological research and innovation. Importantly, however, little attention has been paid to how place-based conditions, and especially the regional context, enable and constrain the development and implementation of normatively framed RRI [4,5]. RRI also fails to recognize responsible innovation as a contested phenomenon. In a regional context, there will be dilemmas regarding the trade-off between the economic, social, and environmental impacts from innovation, and various stakeholders will negotiate interest through discourses and narratives [6]. Moreover, Coenen and Morgan [7] have noted that RRI overlooks critical implementation dimensions, and thus runs the risk of paying insufficient attention to the capabilities and institutions required to innovate responsibly. 
On an empirical level, there is growing interest in responsible innovation within the global salmon farming industry, as dilemmas have arisen from addressing the UN Sustainable Development Goals (SDG). The salmon farming industry is argued to have a huge growth potential as a result of increasingly carbon-conscious diets, but it is also an industry that has been repeatedly challenged by civic communities, regulatory authorities, and others to improve sustainability and beneficial social impacts through innovation and changes to existing practices (i.e., to stimulate responsible innovation). Firms respond through pledges to subscribe and adhere to the SDGs, even though in practice, implementation of these goals might lead to conflict and trade-offs between economic, environmental, and social issues. The essence of these conflicts is often place dependent and localized in a regional context. The Australian salmon farming industry is no exception to these issues. Recently, Knox et al. [8] highlighted the impact of social licenses to operate on public policy processes in Australian marine governance, yet the Australian salmon farming industry stands out as a case that has been remarkably proactive in negotiating its regional dilemmas. The aim of this paper is an in-depth exploration of the place-based drivers behind this example and a discussion about how it can inform the broader literature on place-based directionality of responsible innovations. Specifically, we ask: how do place-based conditions enable and constrain the directionality of responsible innovation in the Tasmanian salmon industry?

To answer this question, we draw together the theories of RRI and regional innovation system (RIS), and the suggestion by Schot and Steinmueller [9] to address discursive narratives in analyses of innovation-related policies. In short, these literatures assist us in defining responsible innovation as a complex of materiality, organization, and discourse. We argue that the RRI literature resembles a perspective on responsibility with a strong bias towards technology research and the development of generic principles on how to ensure a responsible research and process [10]. In contrast, the literature on RIS provides a context-sensitive understanding, emphasizing how the innovation process is organized in interactive systems of firms, R\&D and education institutions, governance actors and other stakeholders [11]. Finally, we argue that the discourse analysis of Fairclough [12] and the concept of narratives can aid us in exploring the discursive dimensions of how to negotiate dilemmas of responsible innovation in RIS.

For our empirical analysis, we applied a recent study on Atlantic salmon production in Tasmania, Australia. There, the dilemmas are linked to negotiating stakeholder interests in economic development and in environmental and global climate change issues in regional contexts. Relying on our innovation complex framework, we investigate how these dilemmas relate to innovation in practice. The analysis demonstrates that recursive links and learning processes between the industry, relevant research, education environments, and regulatory authorities have resulted in an innovation practice in which consideration of climate change and the natural environment are carefully balanced with the interests of businesses and needs to stimulate regional economic development. The outcomes are, among other things, regionally embedded responsible innovation practices that allow for innovation; in this case, recirculating aquaculture system (RAS) technology and locally adapted and developed technologies for remotely controlled open net pen farms, which enable relocation of salmon farming production to more environmentally robust coastal areas.

Theoretically, our case study illustrates the need to conceptualize responsible innovation as an emergent relational phenomenon involving multiple actors and interests. This means that studies of the directionality of innovation, highlighted in the RRI literature, must account for how place-based conditions interplay with what is considered "responsible" by multiple stakeholders. Empirically, the Tasmanian case exemplifies this through its many links to materiality in terms of technologies and resources, to discourse in terms of narratives in play, and to organization in terms of innovation systems and regulations. The outcomes appear tailored to responsible innovation dynamics enabling increased production capacity, new RIS assets, and reduced environmental pressure. Thus, 
we also initiate a theoretical discussion that involves the RRI concept, the RIS literature, and discourse analysis towards addressing place-based directionality of innovations.

\section{Theoretical Framework}

During the last decade, growing concerns over how to cope with SDGs have positioned the RRI literature prominently, especially within policy spheres. This is particularly the case within the European Union, where debates center on European research and innovation policy [1] (i.e., linking research and the impact of research and innovation). This area of inquiry has its roots in the science and technology studies literature, which has long debated topics of science and "responsibility", as exemplified by discussions on the negative impacts of research and how to avoid them [13]. Empirically, it signals that we should not take for granted that innovations are positive for development. Theoretically, it reinforces the notion that the development of innovation is related to institutions. Departing from such discussions, the more recent RRI literature contributes insight on how to ensure research stewardship, and how to make it more inclusive and sustainable. It offers forward-looking approaches, methods, and frames of reference for reflecting on the societal impact of research and innovation. Furthermore, it involves a focus on guidance of research and participatory ways of conducting research and innovation [14].

In its practical application, RRI as a concept typically connotes a focus on science and research. Most RRI is concerned with "a policy and socio-ethical perspective and focusing on academic R\&D environments" [15] (p. 20). However, the explicit link to policy formulation and, in turn, policy implementation, gives RRI a strong normative dimension. As RRI particularly addresses questions such as how to ensure the "right" societal impacts of research and innovation [2], it also opens the opportunity to discuss "desirable" societal benefits. Thus, as it argues for an extended group of legitimate actors who influence policymaking and innovation processes, RRI taps into the issues of normativity, questioning the kinds of public value fostered by research and innovation [14]. In doing so, it resonates with a shift from triple to quadruple helix framings of innovation stakeholders [16], adding the role and interests of citizens and civic organizations. Importantly, though, the principles, methods, and tools for achieving such "beneficial" outcomes, or how to stimulate the "right" processes to achieve these goals, are not given. The RRI literature has been criticized for being particularly occupied with the materiality of innovation, in terms of technology development and research-driven innovation. Much RRI research has investigated the research and innovation process around the development of technologies such as nanotechnology, biotechnology, and various forms of digitalization, with an emphasis on their potential negative impacts [17]. Studies have also addressed how to implement the RRI framework in public research funding institutions throughout Europe and the USA [18]. Accordingly, one characteristic of RRI is a focus on how to conduct responsible science and technology development in a world where innovation is decidedly approached as a linear process extension of science.

In contrast, the RIS approach contributes a broader conceptualization of innovations $[19,20]$. The RIS approach is rooted in the literature on innovation systems, which has been informed by evolutionary economics, economic sociology, and related institutional schools of thoughts [11]. Moreover, the literature on RIS has added a strong emphasis on territorial dimensions and has further developed the idea that innovation processes benefit from the geographical proximity between innovating agents. The literature puts organizations (including research organizations, firms, and policy actors) in their institutional and relational contexts at the core of the innovation process and has become a popular analytical framework for analyzing the regional conditions that enable and constrain innovation [21,22]). Various definitions of a regional innovation system have been developed, but it is common to portray a RIS as a system consisting of three interacting subsystems: a knowledge infrastructure system (i.e., R\&D, educational institutions), an industrial system (i.e., clustering firms), and a governance system (i.e., mediators such as administrative authorities) [23]. It is also common to distinguish between organizationally 
thick/thin and industrially diversified/specialized RIS [24]. Regions with organizationally thick innovation systems more easily facilitate collaboration, exploration, and exploitation of knowledge than regions with organizationally thin innovation systems. The degree of industrial specialization (or conversely diversification) conditions, on the other hand, affects the ability for regions to generate and nurture new development paths. Recent analyses in innovation studies have expanded this to include extra-regional processes (i.e., national and international levels) and have investigated the multilevel geography of innovation processes [25].

It can be argued that most of the RIS literature has been preoccupied with studies of how innovation can promote regional economic growth and competitiveness. Increasingly, the analytical focus is also acknowledging the directionality of change and how innovations can handle the "grand challenges of the society" (such as environmental pollution and social polarization) $[26,27]$. This normative turn makes the role of norms and value (i.e., institutions) even more prominent for innovation processes and systems [28]. This further reinforces the importance of place-based factors and contextualization when analyzing the repertoire of capabilities for responsible innovation in an innovation system (i.e., what firms are doing), relevant enabling and constraining institutions and the main drivers of, and obstacles to, responsible innovation (i.e., why they are/are not doing it). This also implies a need to further conceptualize innovation as a contested phenomenon that involves dissimilar and potentially conflicting interests, norms, and values. There will be dilemmas and trade-offs between economic, social and environmental impacts from innovation, and various stakeholders will assert and negotiate their interests through discourses. Examples of handling this discursive dimension in analyses of innovation systems and policies have been rather limited [9], also in the RRI and the RIS literatures.

To cope with this, we draw on an analytical approach grounded in discourse theory and previously applied in similar analysis of the salmon sector in Norway [6] and in New Zealand [29]. In our former studies of salmon farming industries, we have chosen to supplement the concept of discourse with the concept of narratives. Following Fløysand et al. [29] (pp. 230-231), we define discourse as "the process of producing meaning on a certain topic in a way that inherently structures the perceptions and practices of the participants, who are not necessarily conscious of being controlled [30], while narratives are defined as the specific perceptions or modes of explanations promoted by an actor or group of actors located in a certain discourse" [31,32]. A discourse normally contains several narratives. Thus, a rational for introducing narratives into discourse analysis is that this provides a reflexive analytic tool for mediating discourse. By this we mean that reflections about norms and values related to responsible innovation do not have to be explicitly present in the minds of key stakeholders, but very often come to the surface through claims and storylines about what they perceive as important events and processes for innovation and development. Accordingly, narratives held by stakeholders in an innovation complex may differ, be incoherent and as such be exposed for dilemmas.

In summary, the discussion above assists us in defining responsible innovations as a territorial complex of materiality, organization, and discourse (see Figure 1). The RRI literature, explicitly pointing at innovation as research driven, has been particularly occupied with the materiality of innovation in terms of R\&D-driven technology development; meanwhile, the RIS literature exploring innovation as an interactive phenomenon has highlighted organizations, interrelations, and the territoriality of innovation. Inspired by Schot and Steinmueller [9], the literature review above also directs us to address innovation as a discourse about what it is, what it should be, and what it could become. Departing from the innovation complex model, we will present the development history of the Tasmanian salmon industry in Section 4.1, followed by an analysis of the organizational (Section 4.2), discursive (Section 4.3) and material characteristics (Section 4.4) of the innovation complex of the Tasmanian salmon farming industry. However, before that, we will introduce the methods we have applied to provide data for the analysis. 




Figure 1. The innovation complex (developed by the authors).

\section{Methods}

Following up the innovation complex empirically, we focus on the salmon farming industry in Tasmania where we conducted a qualitative study combining an exploratory and descriptive research design. Taking advantage of previous research experience within the research group, we capitalized on former case studies in the salmon farming industry in Norway [6], New Zealand [29] and Chile [33]. The first step in the case study of the Tasmanian salmon farming industry was to contact potential key informants familiar with the salmon farming industry in the region. When we got hold of several informants, we started to list stakeholders in the industry. In the first phase of the fieldwork, snowball sampling was used, adding new stakeholders to the list as the study proceeded. In total, we listed and contacted 24 stakeholders for a face-to-face interview. Two of these stakeholders were not interested taking part in the study, four did not answer, while two scheduled interviews were cancelled due to practicalities. In the end, our primary data were $16 \mathrm{semi}-$ structured individual (11) and group interviews (5) of 24 interviewees, among whom 7 (distributed across 7 interviews) represented the industry (salmon companies, suppliers, and their business organizations), 9 (across 3 interviews) represented public authorities, 6 (across 4 interviews) represented R\&D institutions, and 2 (across 2 interviews) represented civic society. The stakeholders represented in the case study are: Huon Aquaculture; Huon Whale Point; Tasmanian Salmon Growers Association (TSGA); See 3; Scale AQ; Manolin, Aqui-S; Commonwealth Scientific and Industrial Research Organisation (CSIRO); CSIRO Fish Health; The Institute of Marine and Arctic Studies (IMAS); the Australian Bureau of Agricultural and Resource Economics and Sciences (ABARES); Fisheries Research and Development Corporation (FRDC); Environmental Protection Agency (EPA), Department of Primary Industries, Water and Environment (PIPWE); Nautilus Collaboration; CIA Australian Aquaculture.

The majority of the interviews were face-to-face (three interviews were digital), each lasting 30-90 min and conducted during a fieldwork in Australia in January 2020. The interviews covered questions about the industry and its development and organization, 
political regulations, future challenges, and innovation issues (see Appendix A). We also used secondary data from strategy documents, stakeholders' websites, newsletters, and other sources such as ABC News, the Sustainable Industry Growth Plan for the Salmon Industry [34], Huon Aquaculture Storm Bay Fact Sheet [35] and A Fresh ApproachTasmanian Salmon Consumer Guide [36]. We applied principles of saturation to these qualitative data [37]. First, saturation was applied during the interview phase, such as by closing the search for more stakeholder interviewees when we determined that the same narratives were recurring and that no new insights were gained with additional data sources [38]. For example, some claims and storylines about important events and processes in the industry repeatedly came to the surface in the interviews, such as those about the industry as a driver for local development; the Macquarie Harbour "case", relocation to Storm Bay; the industry as a potential threat for marine environments, etc. (see next section). Saturation was also applied in the manual coding of the interview data to ensure that quotes were sufficiently generic to cover multiple stakeholders (i.e., there was a "consensus across views expressed") [39] (p. 296). In the following discourse analysis, we have superimposed the narratives we observed as most exposed and relevant for the directionality of innovations in the Tasmanian salmon industry.

\section{Results}

\subsection{Development of the Tasmanian Salmon Industry}

The development history of the Tasmanian salmon industry spans less than 40 years. In the early 1980s, interest in salmonids broadened as the Tasmanian Fisheries Development Authority recognized the potential of aquaculture, especially salmon farming, following visits from Norwegian advisors that assessed parts of the coastline as favorable for farming. A ban on fresh salmonid products from 1968 made brood stock and egg importation impossible, so the genetics program needed to be based on earlier imported, landlocked Atlantic salmon brought to mainland Australia (New South Wales) from Canada [40]. In February 1985, Salmon Enterprises of Tasmania (SALTAS) was established as a joint venture between the state government (51\%), the Norwegian company Noraqua (19\%), and local salmon growers $(30 \%)$. Their agreement allowed transfer of technology from Noraqua to assist the development of the industry in Tasmania [40]. SALTAS' general objectives were training of suitable, qualified staff to develop a high-quality brood stock of Atlantic salmon, including a selective breeding and genetic research center; a hatchery producing at least one million smolts/year, and a sea farm capable of producing approximately 100 metric tons fish/year. A sea farm was established in Dover, approximately $130 \mathrm{~km}$ south of Hobart, and a hatchery was developed at Wayatinah in the Central Highlands (see Figure 2). By 1987, 18 marine farming permits (i.e., leases) for salmonid farming had been issued in Tasmania. Over the following 15 years, production increased to 16,686 t in 2003-2004 (see Figure 3). In the next decade, a significant expansion led to a total of 41,615 $\mathrm{t}$ in 2013-2014 [41]. Currently, Tasmania produces approximately 64,000 $\mathrm{t}$ [42].

Although these values represent a relatively modest share of global production, the salmon industry has become the largest primary industry in the Tasmanian state. By volume, it represents Australia's largest seafood product and employs the nation's largest number of people in the aquaculture sector [42]. The industry has also shown strong growth in GVP. In 2017-2018, salmonid production value increased by 13\% to AUD 838.3 million, which was driven by a $17 \%$ increase in production volume (see Figure 3). Most production $(96 \%)$ is aimed at the domestic fresh fish market. Nevertheless, industry growth has been relaxed compared with salmon farming regions elsewhere. Scarce sheltered production locations have especially slowed growth. The industry has also undergone restructuring. During the past decade, the number of firms operating marine farms has been reduced to three. Nevertheless, as the scale of Tasmanian salmon production has increased, so too has the ancillary sector; jobs created through salmon farming are estimated in the order of 5200, including around 1600 jobs directly within the industry [42]. In 2009, the industry set 
a goal of reaching AUD 1 billion before 2030; this is now recognized as a modest goal, as the current gross revenue is AUD 762 million, with a year-on-year growth of $9 \%$.



Figure 2. Marine farming development plans and related marine farming zones (developed by the authors).

1500

1200



100

80

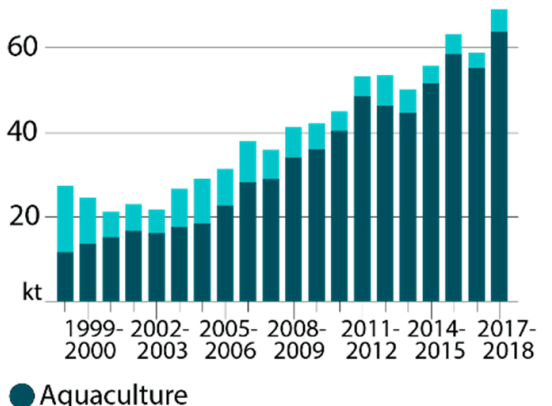

Figure 3. Tasmanian fisheries and aquaculture GVP (in million AUD) and production volume by sector, 1998-1999 to 2017-2018 (Source: Australian Bureau of Agricultural and Resource Economics and Sciences (ABARES) [42]).

\subsection{Organization: Innovation System and Regulations}

The Tasmanian salmon industry is part of what we described in the theory section as a RIS. The system is characterized by few, strong local firms and R\&D actors sustained by regional regulating public authorities. The industry subgroup of the RIS includes the salmon firms that were until very recently dominated by the three locally controlled salmon farming firms: Huon Aquaculture, Tassal Group, and Petuna (taken over by New Zealand 
Sealord in February 2020), suppliers, and their business association: Tasmanian Salmon Growers Association (TSGA). Accordingly, the salmon farming industry has been mainly controlled by Tasmanian capital. In addition, the RIS contains a solid knowledge infrastructure system, embracing basic research bodies such as the Commonwealth Scientific and Industrial Research Organization, the University of Tasmania, and applied research institutes such as the Institute of Marine and Arctic Studies. The governance system includes national public authorities such as Australian Bureau of Agricultural and Resource Economics and Sciences and Fisheries Research and Development Corporation, regional public authorities such as the Environmental Protection Agency (EPA), the Department of Primary Industries, Water and Environment (PIPWE), and the Marine Farming Planning Review Panel. The latter is a relatively new governance institution, created to meet the public's need for transparency and independence of environmental regulation. Finally, the RIS consists of a civic society of local communities, non-governmental organizations (NGOs), media groups, etc. Though some of these civic society actors are not directly involved in regulation efforts or new technology development, their narratives are important to the directionality of the innovations complex.

The regulation of marine and freshwater salmon farms in Australia is based on the 2017 Finfish Farming Environmental Regulation Act, which introduced a dual consent process for new aquaculture farms whereby marine farmers must first apply for a coastal permit from PIPWE before applying for a fishery permit from the EPA. Firms must then comply with marine farming development plans and related marine farming zones (MFZs) - each of which can be specified as suitable for certain activities.

In addition, the regional regulation authorities require substantial environmental monitoring of onshore farming (i.e., RAS technology), including quarterly ground water testing, surface water testing during heavy rainfall, odor monitoring, and noise sampling. Meanwhile, offshore farming (i.e., offshore open net pen technology) monitoring includes water temperature, salinity, dissolved oxygen, ambient phytoplankton and zooplankton, net fouling, and marine debris [43,44]. To analyze the Tasmanian industry's responsiveness to these regulations, we turn to the discursive dimensions of the innovation complex.

\subsection{Discourse: Narratives in Play}

One dilemma of the Tasmanian salmon industry is to balance investments and growth with environmental and social pressure, allowing local economic value capture. This dilemma comes to the surface through what we interpret as the local development narrative and the environmental degradation narrative. From one perspective, salmon farming is considered important for economic growth; from other perspectives, it is considered as a rather volume-oriented growth strategy evoking concerns among consumers, non-governmental organizations (NGOs), politicians, and others about the impact of the industry on the environment and societal development. To illustrate this, we delve into the discourse dimension of the innovation complex (the process of producing meaning on a certain topic i.e., the Tasmanian salmon farming industry) and how the stakeholders in the interviews express such processes through narratives, i.e., specific perceptions or modes of explanations. The first striking perception promoted in the discourse surrounding the industry is storylines about local commitments and a strong Tasmanian identity, as well as polarized claims about the industry's impacts. We interpret this as a local development narrative activated to both criticize and support the industry:

"It's just the makeup of who we are as Tasmanians. And I make that distinction as opposed to Australians.... we are really fiercely proud of the things that have been invented. I think also it goes to the nature of Peter and Francis that they have been born and bred in the Huon Valley. It's why their company's called Huon. They both came from farming backgrounds and Francis's father was a fisherman, you know, heavily involved in creating sustainability and resilience in some of our regional towns."

(industry) 
"It's very polar. .... Jobs are described by the local governments and by the state government as a huge driving factor for supporting the salmon industry, but the actual community is much divided. There is a mixture of people who've come down from the mainland who are retirees where the attitude is very much 'not in my backyard.' There are people who have come down to try to make a life for themselves and the jobs are great. And then there are what we call Greenies where the salmon industry was just coming under a significant amount of attack. .... It's a, it's a very challenging space. The jobs are definitely not enough."

(civic society)

To understand this double-edged social pressure expressed in the local development narrative, we must, as hinted in the last quote, pay the perceptions of the greenies a visit. Several of our informants referred to environmentalism associated with claims about the industry's negative environmental footprint as a key driver or barrier for development processes in the sector. Thus, the second striking perception promoted in the interviews is what we interpret as the environmental degradation narrative expressing a strong consideration for the negative ecological impacts from the industry. For example, in a report rating the industry published by the NGO Environment Tasmania, it is stated that "[ ... ] all score poorly on major sustainability and animal welfare indicators [ ... ] Overall, we are unable to advise that consumers concerned about the environment or animal welfare purchase Tasmanian farmed salmon at this time." [36] (p. 2). In addition, the environmental degradation narrative has been fueled by severe salmon mortality in one of the core MFZs, Macquarie Harbour (see Figure 3). In 2012, the Tasmanian Government approved an expansion of salmon farm production in that location from 8000 metric tons to 29,500 metric tons. Keeping in mind that Macquarie Harbour is an approximately $276 \mathrm{~km}^{2}$ shallow inlet, with an average depth of $15 \mathrm{~m}$, this decision has been seen by many as an ecological failure, for example by NGO Environment Tasmania, who stated "We're shocked that the government has approved an increase of fish farm numbers in Macquarie Harbour considering that the dissolved oxygen levels there are still considered at an all-time low. ... We will certainly be investigating the rationale of those increased productions and we will be looking for any possible avenues to challenge that decision" [45]. Similar perceptions are evident in our interviews:

“We shouldn't have expanded salmon farming in Macquarie Harbour, but the decision was made [...]. There was salmon farming in Macquarie Harbour for years and years before the industry looked to expand it. That really came to a head and caused a lot of public discussion about whether aquaculture should be there and how it should be done. They environmental models didn't work, at Macquarie Harbor the waters are difficult."

(R\&D institution)

"Macquarie Harbor is probably the best example of the worst."

(public authority)

In the following years of increased farming activity, the area experienced deteriorating benthic conditions, especially low dissolved oxygen levels in the middle and bottom waters during spring 2016 [46]. During the warm summer of 2017-2018, health issues such as pilchard orthomyxovirus (also known as "POMV") led to calls for reducing these farming sites. The regulatory authorities were accused by NGOs, industry players, and by others of allowing companies to farm salmon in numbers far greater than Macquarie Harbour could sustain. Whether due to temperature rise, overstocking, or a combination of these, poor production conditions for salmon in Macquarie Harbour created a heated debate about the sustainability of the Tasmanian salmon farming industry. Two of the leading salmon farming companies disagree on how to cope with the situation. For example, during the hot periods of the 2015-2016 summer, Tassal's CEO stated that "all of Tassal's fish stock are from our selective breeding program, which has focused on breeding fish adapted for Tasmanian 
conditions" [47], meaning they are more resilient to higher temperatures and challenging water conditions. In contrast, Huon Aquaculture argued, in their semiannual report, that rising water temperatures put Macquarie Harbour under additional stress from falling water oxygen levels [48]:

"Huon took the government to the federal court ... we took legal action against state government and the regulator, which is significant. So, our, our position on Macquarie Harbor is extremely clear."

(industry leader)

As illustrated by this quote, the Macquarie Harbour situation is a delicate one. Nevertheless, in the end, the Macquarie Harbour situation has strengthened the environmental degradation narrative across stakeholder groups. For example, the Tasmanian Greens Senator Peter Whish-Wilson calls for more transparency in the industry "This [the Macquarie Harbour situation] is a significant matter of public interest, and the impact on fish growth is not just an issue for the salmon companies and their profits and shareholders, but it's also an issue for Tasmanian communities around the salmon farms, the recreational fishery, as well as the broader ecosystem" [49]. This perception of a need for more transparency is shared by our informants:

"My reading of most of the population, and that's my area, is that as long as the salmon industry is able to explain what it's doing and, and is transparent about when it gets it wrong or what could be better, most of the population will support the aquaculture. But there's a really, really well orchestrated, um, you could say attack from environmental organizations about, about how the industry is getting it wrong."

(R\&D institution)

Currently, the Tasmania EPA is relocating farms from MFZs that are exposed to temperatures above the threshold for salmon farming to cooler, more open sea exposed MFZs:

"I think the industry is very challenged by the very restrictive nature of the zones that have been allocated for aquaculture and it's pretty much forcing, forcing this move gradually offshore."

(R\&D institution)

Changes in the materiality of the Tasmanian salmon industry innovation complex seems to sustain the above statement.

\subsection{Materiality: New Technologies}

Along with increasing support for the environmental degradation narrative, key stakeholders of the RIS are exposed to a dilemma of how to generate economic growth while at the same time reducing the ecological pressure in their most central production areas. To cope with this dilemma, the industry has shown increased concern for introducing new technologies. In particular, the new offshore open net pen technology under development in the complex indicates how place-based interplays between organizational conditions (a mature RIS, civic players and new regulations) and discursive conditions (narratives in play) can stimulate the creation of new technologies that enable relocating salmon farming production from vulnerable coastal areas to more environmentally robust coastal areas.

In early 2019, Huon Aquaculture completed the Whale Point Nursery, the largest RAS system for Atlantic salmon production in the southern hemisphere. The facility recycles $98 \%$ of the intake water, manages and utilizes waste, and is expected to reduce farming time at sea from 14 months to 9-10 months by rearing smolt over one kilo before sea transfer. Whale Point Nursery has 800 cubic meters of grow-out tanks and 220 cubic meters of smaller grading tanks [35]. According to our informants, introducing RAS technology to Tasmania resulted in increased production capacity: 
"So, in terms of technology innovation, we're moving on shore in Tasmania. So, the salmon companies invested a lot of money in onshore hatchery technology."

(R\&D institution)

"A year ago, we opened the Southern hemisphere's first salmon nursery. So, we've grown smolt to a $\mathrm{kg} 1.2$... . I actually think we'll make some announcements in the next two months which will blow that one out of the water, even bigger."

(industry leader)

While increased production capacity in the salmon farming industry is highlighted by the industry, one must also be mindful of the significantly increased energy usage, and thus $\mathrm{CO}_{2}$ emissions, of such complex, energy demanding processes. While, the RAS technology is a standardized, footloose technology imported to Tasmania, other technologies are more tailored and locally developed. This is the case for a new form of remotely controlled offshore open net pen technology operating in areas with wave heights of up to $10 \mathrm{~m}$. Offshore aquaculture farming is the practice of placing farms away from the coast, in high-energy areas, which places increased demands on the robustness and control of the installation and farmed fish. Exploratory and place-tailored net pens are underway in Storm Bay [35], where proposals are now moving through the statutory planning stage. From 2014, Huon Aquaculture began farming high-energy sites in Storm Bay as part of a strategy to move some of their production in shallow inshore sites to sites with better water flow and sufficient distancing to reduce disease transfer:

"Look at what, how many fish you can put in storm Bay. That process is already underway and $\mathrm{x}$ and $\mathrm{I}$ and $\mathrm{y}$ are running the first step process on the full risk assessment."

(R\&D institution)

"What I'd like to see is us out of the west coast, out of Macquarie Harbor. It's a world heritage area. So smolt in the Huon River, all of our growth out in Storm Bay and further out."

(industry leader)

"Well, as you know, you've got to find the right environment to do aquaculture, you must find bays or waters that are fairly, sort of, manageable. I guess marine aquaculture technology has improved. So, there are sort of proposals like, I don't know if you have heard about the immediate Storm Bay proposal, for a culture that's more in rough waters, I guess. Yeah, so moving away from sort of sheltered waters to rough waters."

(public authority)

Storm Bay has among the roughest farming conditions in the world. To move open net pens offshore, locally controlled salmon farming firms have designed fortress pens that are able to withstand more challenging conditions while simultaneously keeping predators out. The pens are incrementally different from standard net pens. In addition, the local players in the Tasmanian salmon industry have developed well-boats and feed barges specifically designed to handle the required high energy licenses for this site of Storm Bay. The industry has invested more than AUD 100 million in their patented fortress net pens that can handle the rough conditions [50]. Though uncertainties remain about the quantities of biomass the industry will be allowed to farm in Storm Bay, it is estimated that 30,000 metric tons of Atlantic salmon can be farmed with the licenses that have been distributed [35]. 


\section{Discussion}

The aim of this paper has been to explore the place-based conditions enabling and constraining the directionality of responsible innovation in the Tasmanian salmon farming industry, and to discuss how this case can inform the broader literatures on RRI and RIS. Towards this goal, we have argued for understanding innovation as a territorial complex consisting of an organizational dimension in terms of innovation system and regulations, a material dimension in terms of technologies and resources, and a discursive dimension in terms of narratives in play. We have applied the complex to analyze how place-based conditions influence the negotiation of dilemmas linked to processes of innovation in the Tasmanian salmon industry. The analysis found that the Tasmanian salmon farming industry is sustained by, and sustains, a thick organizational and specialized RIS. Further, that a pronounced Tasmanian identity generates community loyalty and stimulates networking between local firms and other local actors, brought together around a collective interest to secure the balanced future development of Tasmania. This is discursively expressed in a co-existing local development narrative geared to secure local value capture and legitimation of the industry in local communities, and an environmental degradation narrative that is of significant influence when it comes to regulations and to innovations in terms of new RAStechnology and open net pen technology. The ability to sustain both narratives at the same time without leading to inertia and gridlock but giving way instead to the development of local solutions is in turn tied to the presence of an organizationally thick RIS.

However, there is always a risk of missing important empirical dimensions in double hermeneutics, in particular in discourse analysis focusing on narratives related to processes of meaning production. Do the scrutinized stakeholders recognize the presented narratives? Do they find the analysis of how the narratives in play, in concert with new regulations, influences RRI and directionality of innovation, reasonable? Although we believe the sampling in this case study partly controls for the validity of the observed narratives in the discourse, a dialogue with our informants to check for their recognition of our research results and conclusions would have increased the validity of the study. Furthermore, whether these new technologies represent truly place-based responsible innovations remains an open question. RAS technology originates in standardized wastewater treatment technology, increasing the productivity per area and unit worker of any aquaculture system [51]. Its main advantages over offshore technologies are water quality management, minimization of external water supply usage, and capture of biological waste products. Compared with traditional systems (e.g., flow-through or pond systems), a high degree of recirculation is achieved by incorporating water treatment processes that yield 90-99\% recycling of intake water. Proponents of RAS technology will emphasize that recirculation and filtration of water yield gains in sustainability, expandability, biosafety, quality, and predictability of harvest [51] (p. 246). Sceptics, on the other hand, highlight that it is very energy consuming, making the return on investment half that of an open net pen farm [52]. The offshore open net pen technology in Tasmania represents a more tailored, place-based developed technology [35], but in terms of responsibility, similar discussions as for RAS can be raised. With regard to emissions, partly moving production to Storm Bay will reduce biomass in sites closer to shore, especially in areas with a low biomass tolerance, such as Macquarie Harbour. By moving pens into more exposed locations in Storm Bay, the waters are colder and more oxygen rich, while also reducing disease spread and the farms ${ }^{\prime}$ eutrophication potential. As such, our study supports the findings by King et al. [53], which suggests that climate change and warming waters is likely to drive significant technological change in Tasmanian salmon farming.

\section{Conclusions}

The analysis of responsible innovation in Tasmanian salmon farming has pointed to empirical insights of how directionality in responsible innovation is sustained by placebased factors pertaining to the materiality-organization-discourse complex (see above). The novelty this brings to the RRI literature is not the observed enabling and constraining 
factors in the case study per se, but rather the underlying assumption of certain "universal" processes driving the directionality of responsible innovation. Under all circumstances, there will be an innovation complex of three interrelated pillars, namely a material, discursive and organizational dimension. The practical implications of these insights are that RRI needs to account for contextual conditions [4].

In addition, this paper offers a theoretical contribution by bridging the RRI and RIS frameworks with the help of discourse theory and analysis to better understand how place-based institutional conditions shape directionality in regional innovation systems. So far, existing RIS studies have relied to a large extent on reading individual behavior from institutional structures [54,55], often drawing on "imported" institutional frameworks such as varieties of capitalism [56]. This approach has provided useful insights to distinguish between different place-based institutional regimes but has proven to be less suitable in understanding institutional dynamics and change [57]. An unfolding shift in regional development policy to go beyond new path development and growth per se, but paying more attention to the direction of innovation and change, and to policy approaches for achieving more sustainable and responsible forms of development [58] offers an opportunity for innovation research to take a more granular perspective to account for changing norms and values in innovation processes and to account for institutional entrepreneurship and other agentic processes when organizations aim to innovate responsibly and navigate the tensions, paradoxes and dilemmas that emerge between different stakeholders as a result. Here, the adopted innovation complex framework provides a useful approach to trace the interconnections between organizations, materiality, and discourses and how these collectively constitute the norms and values that guide directionality in instances of responsible innovation. In particular, it seems that discourse analysis could be put to greater use to describe and understand how responsible innovation co-evolves with formal and informal institutions through processes of experimentation and institutional work [59].

The present analysis is somewhat constrained by being a single case study. While the findings demonstrate that place-based factors matter for enabling and constraining directions in responsible innovation, this research design is limited by a somewhat idiosyncratic range of observations. Further insights on place-based factors and conditions for responsible innovation could be leveraged through systematic comparative research. Ideally, such comparisons between regions and countries would go beyond analyses that mainly consider past and present but allow for longitudinal observations to capture evolving directionality in responsible innovation "in real time" that also accounts for temporal aspects and the sociology of expectations that is at play when discourses and narratives of responsible innovations unfold over time and space [60].

Author Contributions: Conceptualization: all authors. Methodology: A.F., E.T.L., S.-E.J.; Analysis: A.F., E.T.L., S.-E.J. Writing, review and editing: All authors. Project administration: A.F. All authors have read and agreed to the published version of the manuscript.

Funding: This research was funded by the Research Council of Norway grant number 299404. The APC was funded by the same grant.

Institutional Review Board Statement: The study was conducted according to the guidelines of the Declaration of Helsinki, and approved by the Institutional Review Board of Western Norway University of Applied Sciences.

Informed Consent Statement: Informed consent was obtained from all subjects involved in the study.

Data Availability Statement: The interview data presented in this study are available on request from the corresponding author. The interviews are not publicly available due to agreements with the informants that only the project owners should have direct access to them.

Acknowledgments: The authors appreciate constructive comments provided by the editors and anonymous reviewers that helped us to improve the paper.

Conflicts of Interest: The authors declare no conflict of interest. The funders had no role in the design of the study; in the collection, analyses, or interpretation of data; in the writing of the manuscript; or in the decision to publish the results. 


\section{Appendix A}

Themes for stakeholders interviews Tasmania Salmon Industry-Stimulate- and catch perceptions and reflections about industry development and innovation

Starting point: Industry players-firm level (salmon companies, suppliers and the regional business organizations)

\section{- Firm characteristics-The biography of the firm}

Describe your firm. What is specific about your company?

Where do you draw human capital from? Local or international? Would you say that you are only active in the salmon farming industry? Bulk- or niche production? Markets, etc.

\section{- Industry structure}

How has the industry developed over the last 10 years? Describe the industry: Regional versus international ownership? FDI-local capital? Few, many companies? Startups? etc.

\section{- Innovation/Technology}

In what activities are you focusing your innovation efforts? Niches, pilots, demonstration projects? How are you working with new technologies like biotech, machine learning, etc.? How much of your innovations is uniquely developed? What are the critical factors for being innovative? What are the blocking mechanisms for innovation? etc.

\section{- Collaboration in innovation (scope and scale)}

Who are the company's main collaborators? How do you collaborate, contracting? JV? Consultants? Who are the legislators? Who are the suppliers? Vertical and horizontal collaboration/competition? How does the industry—academia collaboration look like in Tasmania? Do you collaborate with partners that are traditionally outside of aquaculture? What way? Etc.

\section{- Industry policy/regulations and innovation}

Characteristic of regulation regime: Strengths/weaknesses? Links to new technologies/innovations (drivers?) etc.

\section{- Sustainability and global development challenges}

What innovations? What are the innovations aiming for? Examples? What is blocking the firm from achieving innovations goals? Do you feel to develop more sustainable practices? Who are the advocates of new sustainable innovations? etc.

\section{- The firms/industry's role in regional and place development}

Local impacts? CSR? Regional impacts? Regional strengths/regional assets of importance for the firm/innovations? Dilemmas? Growth/greening, local employer? Competiveness or environmental challenges? etc.

- Drivers of salmon farming in the future

New technologies? In what way more- in what way less sustainable practices? Dilemmas? Growth/greening or employment/local development? Competiveness or environmental protection? Bulk- or niche production? etc.

\section{Starting point: Other stakeholders}

- Organization characteristics-The biography of the organization

Describe your organization. What is specific about your organization?

\section{- Industry characteristics, structure, innovations, dilemmas?}

How has the industry developed over the last 10 years? Describe the industry, ownership, FDI-capital, many established companies? Startups? Etc. The industry point at [example of innovation] as currently hot innovations, reflections? etc. 


\section{- Innovations and technological development}

Where does the innovation origin? How much of the innovation is coming from science / academy and how much is developed in house by experience? STI? DUI? Etc. Is there any successful role model industry in the (case) salmon farming industry? Solutions in short term versus long term, how much is "fire-fighting"? Do you believe salmon farming will continue in the same trajectory (with open pen farming)? How will it evolve? etc.

\section{- Industry policy (regulations and innovation system)}

Characteristic of regulation regime: Characteristic of innovation infrastructure. Innovation system RIS; NIS; GIN? Strengths and failures? Links to current innovations? What do you think about the industry claiming that the drivers for the [example of innovation] innovation are [reason]? Alternative views/perceptions? etc.

\section{- Collaboration patterns with and within the industry}

Thick/thin RIS?: Position in interacting subsystems: knowledge infrastructure system (i.e. R\&D, educational institutions); industrial system (i.e. clustering firms); and a governance system (i.e. mediators such as administrative authorities) Diversified/specialized? Multiple/few R\&D institutions and intermediate organizations? Various/limited sectors and technology fields? A total different innovation system from RIS, a GIS or rather a GIN? etc.

\section{- Sustainability and (global) development challenges}

What innovations? What are the innovations aiming for? Examples? What is blocking for achieving innovations goals? Who are the advocates of new sustainable innovations? Sustainable technology development: examples? Mission orientated governance of innovation systems, Dilemmas? Acknowledging dilemmas? etc.

\section{- The industry's role in regional and place development}

Local impacts? CSR? Regional impacts? Regional strengths/regional assets of importance for the firm/innovations? Dilemmas? Growth/greening or employment/local development? Competiveness or environmental protection? What is specific about (case) salmon farming industry? Similarities and differences with other salmon producing regions? etc.

\section{- Drivers of the future of salmon farming}

New technologies? In what way more- in what way less sustainable practices? Dilemmas? Growth/greening or employment/local development? Competiveness or environmental protection? Bulk- or niche production? etc.

\section{References}

1. von Schomberg, R. A Vision of Responsible Innovation. In Responsible Innovation; Owen, R., Heintz, M., Bessant, J., Eds.; John Wiley: London, UK, 2013; pp. 51-74.

2. Stilgoe, S.; Guston, D.H. Responsible Research and Innovation. In The Handbook of Science and Technology Studies; MIT Press: Cambridge, MA, USA, 2017.

3. Ribeiro, B.; Bengtsson, L.; Benneworth, P.; Bührer, S.; Martínez, E.C.; Hansen, M.; Jarmai, K.; Lindner, R.; Peñuel, J.O.; Ott, C.; et al. Introducing the dilemma of societal alignment for inclusive and responsible research and innovation. J. Responsible Innov. 2018, 5, 316-331. [CrossRef]

4. Jakobsen, S.-E.; Fløysand, A.; Overton, J. Expanding the field of responsible research and innovation (RRI)—From responsible research to responsible innovation. Eur. Plan. Stud. 2019, 27, 2329-2343. [CrossRef]

5. Fitjar, R.D.; Benneworth, P.; Asheim, B.T. Towards regional responsible research and innovation? Integrating RRI and RIS3 in European innovation policy. Sci. Public Policy 2019, 46, 772-783. [CrossRef]

6. Fløysand, A.; Jakobsen, S.-E. Industrial renewal: Narratives in play in the development of green technologies in the Norwegian salmong farming industry. Geogr. J. 2017, 182, 140-151. [CrossRef]

7. Coenen, L.; Morgan, K. Evolving geographies of innovation: Existing paradigms, critiques and possible alternatives. Norsk Geogr. Tidsskr. (Nor. J. Geogr.) 2020, 74, 13-24. [CrossRef] 
8. Knox, C.C.; Haward, M.; Jabour, J.; Ogier, E.; Tracey, S.R. The social licence to operate and its role in marine governance: Insights from Australia. Mar. Policy 2017, 79, 70-77. [CrossRef]

9. Schot, J.; Steinmueller, E. Three frames for innovation policy: R\&D, systems of innovation and transformative change. Res. Policy 2018, 47, 1554-1567. [CrossRef]

10. Stilgoe, J.; Owen, R.; Macnaghten, P. Developing a framework for responsible innovation. Res. Policy 2013, 42, 1568-1580. [CrossRef]

11. Asheim, B.T.; Isaksen, A.; Trippl, M. Advanced Introduction to Regional Innovation Systems; Edward Elgar Publishing: Cheltenham, UK, 2019.

12. Fairclough, N. Critical Discourse Analysis. The Critical Study of Language; Longman: London, UK, 1995.

13. Zwart, H.; Landeweerd, L.; van Rooij, A. Adapt or perish? Assessing the recent shift in the European research funding arena from 'ELSA' to 'RRI'. Life Sci. Soc. Policy 2014, 10, 11. [CrossRef] [PubMed]

14. Uyarra, E.; Ribeiro, B.; Clough, L.D. Exploring the normative turn in regional innovation policy: Responsibility and the quest for public value. Eur. Plan. Stud. 2019, 27, 2359-2375. [CrossRef]

15. Blok, V.; Lemmens, P. The Emerging Concept of Responsible Innovation. Three Reasons Why It is Questionable and Calls for a Radical Transformation of the Concept of Innovation. In Responsible Innovation, 2nd ed.; Koops, B.J., Oosterlaken, I., Romijn, H., Swierstra, T., van den Hoven, J., Eds.; Springer: Cham, Switzerland, 2015.

16. Carayannis, E.G.; Campbell, D.F.J. "Mode 3" and "Quadruple Helix": Toward a 21st century fractal innovation ecosystem. Int. J. Technol. Manag. 2009, 46, 201-234. [CrossRef]

17. Thapa, R.K.; Iakovleva, T.; Foss, L. Responsible research and innovation: A systematic review of the literature and its application to regional studies. Eur. Plan. Stud. 2019, 27, 2470-2490. [CrossRef]

18. Kerr, A.; Hill, R.L.; Till, C. The limits of responsible innovation: Exploring care, vulnerability and precision medicine. Technol. Soc. 2018, 52, 24-31. [CrossRef]

19. Boschma, R.A.; Frenken, K. Why is economic geography not an evolutionary science? Towards an evolutionary economic geography. J. Econ. Geogr. 2006, 6, 273-302. [CrossRef]

20. Coenen, L.; Asheim, B.; Bugge, M.M.; Herstad, S.J. Advancing regional innovation systems: What does evolutionary economic geography bring to the policy table? Environ. Plan. C Politics Space 2017, 35, 600-620. [CrossRef]

21. Njøs, R.; Jakobsen, S.-E. Policy for evolution of regional innovation systems: The role of social capital and regional particularities. Sci. Public Policy 2018, 45, 257-268. [CrossRef]

22. Doloreux, D.; Gomez, I.P. A review of (almost) 20 years of regional innovation system research. Eur. Plan. Stud. 2017, 25, 371-387. [CrossRef]

23. Stuck, J.; Broekel, T.; Diez, J.R. Network structures in regional innovation systems. Eur. Plan. Stud. 2016, 24, 423-442. [CrossRef]

24. Isaksen, A.; Trippl, M. Regional industrial path development in different regional innovation systems: A conceptual analysis. Pap. Innov. Stud. 2014, 17, 1-18.

25. Njøs, R.; Sjøtun, S.G.; Jakobsen, S.-E.; Fløysand, A. Expanding analyses of path creation: Interconnections between territory and technology. Econ. Geogr. 2020, 96, 266-288. [CrossRef]

26. Schlaile, M.; Urmetzer, S.; Blok, V.; Andersen, A.D.; Timmermans, J.; Mueller, M.; Fagerberg, J.; Pyka, A. Innovation systems for transformation towards sustainability? Taking the normative dimension seriously. Sustainability 2017, 9, 2553. [CrossRef]

27. Weber, K.M.; Truffer, B. Moving innovation system research to the next level: Towards an integrative agenda. Oxf. Rev. Econ. Policy 2017, 33, 101-122. [CrossRef]

28. Mazzucato, M. The Value of Everything: Making and Taking in the Global Economy; Public Affairs: New York, NY, USA, 2018.

29. Fløysand, A.; Håland, K.; Jakobsen, S.E. Discourses, risk perceptions and the "green" profile of the New Zealand salmon farming industry. Mar. Policy 2016, 74, 230-235. [CrossRef]

30. Rose, G. Visual Methodologies: An Introduction to the Interpretation of Visual Material; Sage Publications: London, UK, 2001.

31. Roe, E.M. Development narratives, or making the best of blueprint development. World Dev. 1991, 19, 287-300. [CrossRef]

32. Swift, J. Desertification: Narratives, winners \& losers. In The Lie of the Land: Challenging Received Wisdom on the African Environment; Leach, M., Mearns, R., Eds.; Heinemann: West Orange, NJ, USA, 1996; pp. 73-90.

33. Barton, J.R.; Fløysand, A. The Political Ecology of Chilean Salmon Aquaculture, 1982-2010: A trajectory from economic development to global sustainability. Glob. Environ. Chang. 2010, 20, 739-752. [CrossRef]

34. Department of Primary Industries, Parks, Water and Environment. Sustainable Industry Growth Plan for the Salmon Industry. Available online: http:/ / www.dpipwe.tas.gov.au/salmonplan (accessed on 26 May 2020).

35. Huon Aquaculture. Appendix 16: Storm Bay Fact Sheet; Publisher: Hobart, Tasmania, 2019.

36. Environment Tasmania. A Fresh Approach—Tasmanian Salmon Consumer Guide. Available online: https://www.salmon.org. au/about (accessed on 26 May 2020).

37. Saunders, B.; Sim, J.; Kingstone, T.; Baker, S.; Waterfield, J.; Bartlam, B.; Burroughs, H.; Jinks, C. Saturation in qualitative research: Exploring its conceptualization and operationalization. Qual. Quant. 2018, 52, 1893-1907. [CrossRef] [PubMed]

38. Bowen, G.A. Naturalistic inquiry and the saturation concept: A research note. Qual. Res. 2008, 5, 137-152. [CrossRef]

39. Turner, A.; Barlow, J.; Ilbery, B. Play hurt, live hurt: Living with and managing osteoarthritis from the perspective of exprofessional footballers. J. Health Psychol. 2002, 7, 285-301. [CrossRef] [PubMed] 
40. Jungalwalla, P.J. The Development of an Integrated Saltwater Salmonid Farming Industry in Tasmania, Australia. In Special Session on Salmonid Aquaculture, Proceedings of the World Aquaculture Society, Los Angeles, CA, USA, 16 February 1989; Cook, R.H., Pennell, W., Eds.; Canadian Technical Report of Fisheries and Aquatic Sciences: Ottawa, ON, Canada, 1991; Volume 1831, pp. 65-73.

41. The Senate. Environment and Communications References Committee. Regulation of the Fin-Fish Aquaculture Industry in Tasmania. Commonwealth of Australia. 2015; ISBN 978-1-76010-276-. Available online: https://www.aph.gov.au/parliamentary_ business/committees/senate/environment_and_communications/fin-fish/ \{\}/media/Committees/ec_ctte/Fin_Fish/report. pdf (accessed on 26 May 2020).

42. Australian Bureau of Agricultural and Resource Economics and Sciences (ABARES). Australian Fisheries and Aquaculture Statistics. Available online: https:/ / daff.ent.sirsidynix.net.au/client/en_AU/search/asset/1030241/0 (accessed on 11 May 2020).

43. Pecl, G.T.; Ogier, E.; Jennings, S.; Pecl, G.T.; Ogier, E.; Jennings, S.; van Putten, I.; Crawford, C.; Fogarty, H.; Frusher, S.; et al. Autonomous adaptation to climate-driven change in marine biodiversity in a global marine hotspot. Ambio 2019, 48, 1498-1515. [CrossRef] [PubMed]

44. IMAS: University of Tasmania-Institute for Marine and Antarctic Studies. Salmon Aquaculture: Monitoring and Management. 2020. Available online: https:/ / www.imas.utas.edu.au/research/fisheries-and-aquaculture/projects/projects/salmonaquaculture-monitoring-and-management (accessed on 11 May 2020).

45. ABC News. Environmentalists Ready to Fight Increase in Salmon Farming in Macquarie Harbour. Available online: https:/ /www. abc.net.au/news/2016-04-29/environmentalists-ready-to-fight-increase-in-salmon-farming/7368882 (accessed on 11 May 2020).

46. Ross, J.; MacLeod, C. Environmental Research in Macquarie Harbour-Interim Synopsis of Benthic and Water Column Conditions; Report to EPA and DPIPWE; Institute for Marine and Antarctic Studies (IMAS), University of Tasmania: Hobart, Australia, February 2017.

47. ABC News. Tassal Declares Macquarie Harbour Salmon Farming Sustainable After State's Hottest Summer. Available online: https: / / www.abc.net.au/news/2016-03-01/tassal-declares-macquarie-harbour-salmon-farming-sustainable/7210338 (accessed on 11 May 2020).

48. ABC News. Hot Weather Reducing Salmon Production, Tasmanian Aquaculture Company Says. Available online: https: //www.abc.net.au/news/2016-02-26/salmon-producer-huon-aquaculturehot-weather-lower-production/7203708 (accessed on 11 May 2020).

49. ABC News. Tasmanian Salmon: Hope Falling Water Temperatures Will Help Local Farmers. Available online: https://www.abc. net.au/news/2016-04-08/cooler-waters-signal-relief-for-tas-salmon-producers/7310944 (accessed on 11 May 2020).

50. Huon Aquaculture. Whale Point Salmon Nursery-Australia's First Onshore Salmon Nursery. Available online: https://www. huonaqua.com.au/about/operations/whale-point-salmon-nursery/ (accessed on 26 May 2020).

51. Tidwell, J.H. Recirculating Aquaculture Systems. In Aquaculture Production Systems; Tidwell, J.H., Ed.; Wiley-Blackwell, Kentucky State University Division of Aquaculture Frankfort: Frankfort, KY, USA, 2012. [CrossRef]

52. Liu, Y.; Rosten, T.W.; Henriksen, K.; Hognes, E.S.; Summerfelt, S.; Vinci, B. Comparative economic performance and carbon footprint of two farming models for producing Atlantic salmon (Salmo alar): Land-based closed containment system in freshwater and open net pen in seawater. Aquac. Eng. 2016, 71, 1-12. [CrossRef]

53. King, A.S.; Elliott, N.G.; James, M.A.; MacLeod, C.K.; Bjorndal, T. Technology selection-The impact of economic risk on decision making. Aquac. Econ. Manag. 2016, 22, 383-409. [CrossRef]

54. Gertler, M.S. Rules of the game: The place of institutions in regional economic change. Reg. Stud. 2010, 44, 1-15. [CrossRef]

55. Fløysand, A.; Jakobsen, S.-E. The complexity of innovation. A relational turn. Prog. Hum. Geogr. 2011, 35, 328-344. [CrossRef]

56. Asheim, B.T.; Coenen, L. Contextualising regional innovation systems in a globalising learning economy: On knowledge bases and institutional frameworks. J. Technol. Transf. 2006, 31, 163-173. [CrossRef]

57. Grillitsch, M.; Sotarauta, M. Trinity of change agency, regional development paths and opportunity spaces. Prog. Hum. Geogr. 2020, 44, 704-723. [CrossRef]

58. Boschma, R.; Coenen, L.; Frenken, K.; Truffer, B. Towards a Theory of Regional Diversification: Combining Insights from Evolutionary Economic Geography and Transition Studies. Reg. Stud. 2017, 51, 31-45. [CrossRef]

59. Tödtling, F.; Trippl, M. Regional innovation policies for new path development-beyond neo-liberal and traditional systemic views. Eur. Plan. Stud. 2018, 26, 1-17. [CrossRef]

60. Steen, M. Reconsidering path creation in economic geography: Aspects of agency, temporality and methods. Eur. Plan. Stud. 2016, 24, 1605-1622. [CrossRef] 